\title{
The profile of anxiety, stress, and depression among pharmacy students in Universitas Islam Indonesia
}

\section{Gambaran kecemasan, stress, dan depresi mahasiswa di Jurusan Farmasi, Universitas Islam Indonesia}

\author{
Mutiara Herawati1 ${ }^{1}$ Aldia Karinaningrum², Yosi Febrianti ${ }^{1}$
}

1Jurusan Farmasi, FMIPA, Universitas Islam Indonesia, Yogyakarta

${ }^{2}$ Magister Framasi Klinik, Universitas Gadjah Mada, Yogyakarta

*Corresponding author: mutiara.herawati@uii.ac.id

\begin{abstract}
Background: Implementation of the new curriculum is tiresome for both lecturers and students. Students who are passive and have limited cognitive abilities will feel depressed. This condition can cause anxiety leading to stress and ultimately depression. The enhancement of graduation standard for apothecary students rises the depression risk factors, especially for retaker students (students who do not pass the Indonesian Pharmacist Competency Exam).

Objective: This study aimed to identify the level of anxiety, stress, and depression among undergraduate pharmacy and pharmacist profession students.

Method: This study was a cross-sectional design that employed the students of undergraduate and apothecary program. Respondents involved in this study were undergraduate students in $2^{\text {nd }}, 3^{\text {rd }}$, and $4^{\text {th }}$ year $(n=451)$ and professional students from batches 35, 36, and $37(\mathrm{n}=271)$. The DASS 42 questionnaire (Depression Anxiety Stress Scale) was used to identify depression. The data was analyzed descriptively.

Result: The number of respondents who met the inclusion criteria was 668. Most undergraduate students had moderate levels of anxiety, normal stress, and normal depression, while apothecary students had normal profiles for all parameters.

Conclusion: The various activities and pressure during learning process triggered psychological disorder for only $5 \%$ of respondent.

Keywords: Anxiety, stress, depression, DASS-42

\section{Intisari}

Latar belakang: Implementasi kurikulum baru sangat menguras pikiran dan tenaga, baik dosen maupun mahasiswa. Bagi mahasiswa yang pasif dan memiliki kemampuan kognitif terbatas akan merasakan kondisi tertekan. Kondisi tersebut dapat menyebabkan kecemasan yang meningkat menjadi stress dan pada akhirnya depresi. Peningkatan standar kelulusan mahasiswa apoteker berpotensi meningkatkan faktor risiko kejadian depresi, terutama bagi mahasiswa retaker (mahasiwa yang tidak lulus Ujian Kompetensi Apoteker Indonesia). Tujuan: Penelitian ini bertujuan untuk mengidentifikasi tingkat kecemasan, stress, dan depresi mahasiswa S1 farmasi dan profesi apoteker.

Metode: Penelitian menggunakan rancangan cross-sectional kepada mahasiswa program studi farmasi dan profesi apoteker. Responden yang terlibat dalam penelitian ini adalah mahasiswa strata pertama pada tahun ke-2,3, dan $4(\mathrm{n}=451)$ serta mahasiswa profesi angkatan 35, 36, dan $37(\mathrm{n}=271)$. Alat yang digunakan untuk mengidentifikasi depresi adalah kuesioner DASS 42 (Depression Anxiety Stress Scale). Data yang diolah secara deskriptif.

Hasil: Jumlah responden yang sesuai dengan kriteria inklusi sebanyak 668. Mayoritas mahasiswa S1 memiliki profil tingkat kecemasan sedang, stress normal, dan depresi normal, sedangkan pada mahasiswa profesi apoteker memiliki profil tingkat kecemasan, stress, dan depresi normal. increase
\end{abstract}


Kesimpulan: Dengan berbagai aktivitas dan tekanan selama proses pembelajaran, mayoritas mahasiswa tidak mengalami gangguan psikis, meskipun $5 \%$ diantaranya menyatakan mengalami gangguan.

Kata kunci : Kecemasan, stress, depresi, DASS-42

\section{Pendahuluan}

Perubahan kurikulum dalam program studi ini berdampak pada proses pembelajaran mahasiswa. Selain adanya perubahan kurikulum, penerapan penilaian berbasis capaian pembelajaran mata kuliah (CPMK) menuntut mahasiswa untuk lebih aktif dan giat dalam proses belajar. Disamping itu, hasil penelitian dengan judul Anxiety and depression among medical students: A cross-sectional study menunjukkan bahwa mahasiswa kesehatan salah satunya kedokteran, merupakan kelompok rentan yang memiliki prevalensi tinggi morbiditas psikiatri yang terdiri dari kecemasan dan depresi (Jadoon NA, Yaqoob R, Raza A, Shehzad MA, Zeshan SC, 2010).

Implementasi kurikulum baru maupun penilaian berbasis CPMK tentunya sangat menguras pikiran dan tenaga. Dari hasil observasi, mahasiswa seringkali mengeluhkan padatnya materi dan tugas kuliah. Hal ini dapat menurunkan produktivitas mahasiswa dalam mengembangkan soft skill nya. Pada kenyataannya, mahasiswa tidak hanya dituntut untuk mengembangkan hard skill melainkan juga soft skill, seperti pengembangan diri dalam berbagai aspek organisasi. Tanggung jawab dan tuntutan kehidupan akademik pada mahasiswa dapat menjadi bagian stress bahkan dapat berkembang menjadi depresi dan gangguan kecemasan yang dialami oleh mahasiswa. Stress merupakan salah satu reaksi atau respon psikologis manusia saat dihadapkan pada hal-hal yang dirasa telah melampaui batas atau dianggap sulit untuk dihadapi. Menurut Jogaratnam \& Buchanan (2004) stress akademik merupakan tekanan mental dan emosional, atau tension, yang terjadi akibat tuntutan kehidupan kampus, sedangkan depresi dan kecemasan merupakan gangguan mental yang ditandai dengan adanya perasaan tertekan, kelelahan dan mengalami demotivasi. Adapun sumber stress akademik meliputi: situasi yang monoton, tugas yang terlalu banyak, kebisingan, tuntutan yang saling bertentangan, tidak dihargai, diacuhkan, kehilangan kesempatan dan deadline berbagai tugas kuliah.

Survei awal yang dilakukan di prodi farmasi menunjukkan mahasiswa mengeluhkan rasa bosan dengan pertemuan dan tugas kuliah yang sangat padat, sering merasa sakit kepala, perih lambung, sulit tidur, merasa cemas, dan mudah tersinggung. Kondisi di atas menujukkan adanya gejala stress, depresi maupun kecemasan pada mahasiswa. Pada tingkat stress yang sedang sampai dengan berat dapat menghambat pembelajaran. Peningkatan jumlah stress akademik akan menurunkan kemampuan akademik yang berpengaruh terhadap indeks prestasi mahasiswa Potter \& Perry (2005). Berdasarkan gambaran di atas, evaluasi penerapan kurikulum baru di Jurusan

Seminar Nasional Asosiasi Perguruan Tinggi Farmasi Indonesia (APTFI) III-Tantangan Pandemik (covid-19) dalam pembelajaran dan penelitian kefarmasian 16-20 Agustus 2021 (Virtual Conference) 
Farmasi penting untuk dilakukan salah satunya dengan melakukan pengukuran tingkat stress, depresi dan gangguan kecemasan mahasiswa serta analisis tingkat signifikansi gangguan tersebut terhadap indeks prestasi mahasiswa.

\section{Metode}

\subsection{Rancangan penelitian}

Penelitian ini merupakan penelitian observasional dengan rancangan cross-sectional. Pengumpulan data dilakukan secara prospektif menggunakan data primer dari seluruh mahasiswa di Jurusan Farmasi. Instrumen penelitian berupa kuesioner yang berisi identitas responden, pertanyaan mengenai penilaian stress, depresi dan kecemasan yang mengacu pada penelitian sebelumnya (Ashari dan Hartati, 2017).

\subsection{Lokasi penelitian}

Penelitian dilakukan di Jurusan Farmasi, Fakultas Matematika dan Ilmu Pengetahuan Alam, Universitas Islam Indonesia (UII).

\subsection{Populasi penelitian}

Populasi dalam penelitian ini adalah mahasiswa prodi farmasi UII, angkatan 2020 (semester I), 2019 (semester II), 2018 (semester IV), dan 2017 (semester VI) yang berjumlah 451 mahasiswa serta mahasiswa PSPA angkatan 35, 36, dan 37 yang berjumlah 217 mahasiswa.

\subsection{Pengumpulan data dan analisis data}

Instrumen pengumpulan data pada penelitian ini menggunakan kuesioner Depression, Anxiety, Stress, Scales (DASS). Kuesioner terdiri dari 3 domain, yaitu domain depresi, kecemasan dan stress masing- masing mengandung 14 pertanyaan (Lovibond, 1995). Data yang telah diperoleh dianalisis secara deskriptif dalam bentuk jumlah responden.

\section{Hasil dan pembahasan}

\subsection{Demografi responden}

Populasi dalam penelitian ini adalah mahasiswa prodi farmasi UII, angkatan 2020 (semester I), 2019 (semester II), 2018 (semester IV), dan 2017 (semester VI) yang berjumlah 451 mahasiswa dan mahasiswa profesi apoteker angkatan 35, 36, dan 37 yang berjumlah 217 mahasiswa.

Pada Tabel 1 diketahui bahwa dari mahasiswa semester I, II, IV, dan VI sebagian besar mahasiswa berjenis kelamin perempuan dan IPK > 3 terutama pada semester II sebesar 63,33\% (95 responden). Hanya sebagian kecil mahasiswa yang berasal dari SMF dengan jumlah 15 reseponden pada semester I dan semester IV sebanyak 24 responden. Di antara seluruh mahasiswa yang telah 
masuk program studi farmasi, terdapat mahasiswa yang menjadikan farmasi sebagai pilihan kedua ataupun ketiga. Meskipun demikian, mayoritas masih menjadikan farmasi sebagai pilihan pertama saat pendaftaran calon mahasiswa.

Tabel 1. Demografi responden mahasiswa S1 Farmasi

\begin{tabular}{|c|c|c|c|c|}
\hline $\begin{array}{c}\text { Jumlah } \\
\text { Responden }\end{array}$ & $\begin{array}{c}\text { Semester I } \\
n=128\end{array}$ & $\begin{array}{c}\text { Semester II } \\
\mathbf{n}=\mathbf{1 5 0}\end{array}$ & $\begin{array}{c}\text { Semester IV } \\
n=109\end{array}$ & $\begin{array}{c}\text { Semester VI } \\
n=64\end{array}$ \\
\hline \multicolumn{5}{|l|}{ IPK } \\
\hline$<2$ & - & 3 & 1 & 0 \\
\hline $2-3$ & - & 52 & 50 & 26 \\
\hline$>3$ & - & 95 & 58 & 38 \\
\hline \multicolumn{5}{|l|}{ Jenis Kelamin } \\
\hline Laki-Laki & 21 & 24 & 23 & 6 \\
\hline Perempuan & 107 & 126 & 86 & 58 \\
\hline \multicolumn{5}{|l|}{ Asal Jurusan } \\
\hline SMA IPA & 113 & 126 & 85 & 46 \\
\hline SMF & 15 & 24 & 24 & 18 \\
\hline \multicolumn{5}{|c|}{ Pilihan Jurusan Farmasi } \\
\hline ke-1 & 101 & 73 & 65 & 30 \\
\hline ke-2 & 22 & 49 & 37 & 26 \\
\hline ke-3 & 5 & 28 & 7 & 8 \\
\hline \multicolumn{5}{|c|}{ Alasan Memilih Farmasi } \\
\hline Diri Sendiri & 88 & 70 & 66 & 30 \\
\hline $\begin{array}{l}\text { Tertolak } \\
\text { Jurusan Lain }\end{array}$ & 13 & 28 & 17 & 16 \\
\hline Orang Lain & 27 & 52 & 26 & 18 \\
\hline \multicolumn{5}{|c|}{ Jalur Masuk Farmasi } \\
\hline PSB & 33 & 56 & 55 & 25 \\
\hline PBT & 4 & 18 & 14 & 4 \\
\hline CBT UII & 13 & 50 & 23 & 20 \\
\hline CBT Non-UII & 78 & 26 & 17 & 15 \\
\hline \multicolumn{5}{|c|}{ Aktivitas Selain Kuliah } \\
\hline Tidak Ada & 97 & 80 & 45 & 40 \\
\hline Organisasi & 26 & 68 & 64 & 24 \\
\hline Kerja & 5 & 2 & 0 & 0 \\
\hline \multicolumn{5}{|l|}{ Sumber Biaya } \\
\hline Orang Tua & 123 & 145 & 107 & 63 \\
\hline Beasiswa & 4 & 4 & 1 & 1 \\
\hline Lain-Lain & 1 & 1 & 1 & 0 \\
\hline \multicolumn{5}{|l|}{ Tempat Tinggal } \\
\hline Rumah & 109 & 16 & 17 & 4 \\
\hline Kos & 18 & 127 & 91 & 59 \\
\hline Asrama & 1 & 7 & 1 & 1 \\
\hline
\end{tabular}

Seminar Nasional Asosiasi Perguruan Tinggi Farmasi Indonesia (APTFI) III-Tantangan Pandemik (covid-19) dalam pembelajaran dan penelitian kefarmasian 16-20 Agustus 2021 (Virtual Conference) 
Terdapat berbagai alasan mahasiswa memasuki program studi farmasi, yaitu keinginan sendiri, tertolak jurusan lain, dan atas keinginan orang tua. Hasil penelitian menunjukkan beberapa mahasiswa semester II yang memasuki program studi farmasi UII karena keinginan diri sendiri $(n=70)$ dan orang tua $(n=52)$. Hasil ini serupa dengan penelitian sebelumnya bahwa pemilihan program studi di perguruan tinggi dipengaruhi oleh motivasi, status sosial orang tua, pekerjaan yang diharapkan, dan lingkungan belajar (Irmawati, 2008). Selain kuliah, ada mahasiswa yang juga mengikuti organisasi sejumlah 24 responden pada semester IV.

Tabel 2. Demografi responden mahasiswa PSPA

\begin{tabular}{|c|c|c|c|}
\hline \multirow{2}{*}{ Jumlah Responden } & Angkatan 35 & Angkatan 36 & Angkatan 37 \\
\hline & $n=93$ & $n=50$ & $n=74$ \\
\hline \multicolumn{4}{|l|}{ IPK } \\
\hline$<2$ & 0 & 0 & 1 \\
\hline $2-3$ & 3 & 12 & 10 \\
\hline$>3$ & 90 & 36 & 23 \\
\hline \multicolumn{4}{|l|}{ Jenis Kelamin } \\
\hline Laki-Laki & 13 & 15 & 9 \\
\hline Perempuan & 80 & 35 & 65 \\
\hline \multicolumn{4}{|l|}{ Asal Jurusan } \\
\hline SMA IPA & 80 & 42 & 55 \\
\hline SMF & 13 & 8 & 19 \\
\hline \multicolumn{4}{|l|}{ Pilihan Jurusan Farmasi } \\
\hline ke-1 & 56 & 32 & 49 \\
\hline ke-2 & 36 & 18 & 20 \\
\hline ke-3 & 1 & 0 & 5 \\
\hline \multicolumn{4}{|l|}{ Alasan Memilih Farmasi } \\
\hline Diri Sendiri & 57 & 19 & 41 \\
\hline Tertolak Jurusan Lain & 18 & 3 & 18 \\
\hline Orang Lain & 18 & 28 & 15 \\
\hline \multicolumn{4}{|l|}{ Jalur Masuk Farmasi } \\
\hline PSB & 34 & 23 & 8 \\
\hline PBT & 17 & 3 & 15 \\
\hline CBT UII & 21 & 17 & 27 \\
\hline CBT Non-UII & 21 & 7 & 24 \\
\hline \multicolumn{4}{|l|}{ Aktivitas Selain Kuliah } \\
\hline Tidak Ada & 73 & 47 & 61 \\
\hline Organisasi & 11 & 2 & 9 \\
\hline Kerja & 9 & 1 & 4 \\
\hline \multicolumn{4}{|l|}{ Sumber Biaya } \\
\hline Orang Tua & 88 & 2 & 68 \\
\hline Beasiswa & 1 & 46 & 3 \\
\hline Lain-Lain & 4 & 2 & 3 \\
\hline
\end{tabular}




\begin{tabular}{lccc}
\hline \multirow{2}{*}{ Jumlah Responden } & Angkatan 35 & Angkatan 36 & Angkatan 37 \\
\cline { 2 - 4 } & $\mathbf{n = 9 3}$ & $\mathbf{n = 5 0}$ & $\mathbf{n = 7 4}$ \\
\hline Tempat Tinggal & 40 & 16 & 20 \\
Rumah & 52 & 127 & 54 \\
Kos & 1 & 7 & 0 \\
Asrama & & & \\
\hline
\end{tabular}

Tabel 2 menunjukkan bahwa dari mahasiswa PSPA angkatan 35, 36, dan 37 sebagian besar mahasiswa berjenis kelamin perempuan dan IPK > 3 terutama pada angkatan sebesar 96,77\% (90 responden). Sama halnya dengan responden dari mahasiswa S1 Farmasi, mahasiswa PSPA juga menyampaikan alasan memilih farmasi, yaitu karena keinginan sendiri, tertolak jurusan lain, dan atas keinginan orang tua. Hasil penelitian menunjukkan beberapa mahasiswa yang memilih farmasi karena keinginan orang tua sebanyak 28 responden pada angkatan 36. Berbeda halnya dengan mahasiswa S1 Farmasi, mahasiswa PSPA lebih banyak yang tidak mengikuti kegiatan selain kuliah. Hal ini disebakan karena aktivitas kuliah mahasiswa PSPA sangat padat.

Jenis kelamin perempuan menunjukkan jumlah yang jauh lebih banyak dibandingkan lakilaki. Hal ini sejalan dengan kondisi stress, kecemasan, dan depresi yang sering dialami oleh mahasiswi. Hasil tersebut serupa dengan penelitian sebelumnya di Pakistan yang menunjukkan bahwa mahasiswi merupakan mahasiswa yang mendominasi (Ghayas S, Shamim S, Anjum F, Hussain M., 2014).

\subsection{Profil tingkat kecemasan}

Data profil tingkat kecemasan mahasiswa S1 Farmasi dapat dilihat pada Gambar 1. Tingkat kecemasan responden didominasi oleh kategori sedang pada responden seluruh semester, namun responden yang memiliki tingkat kecemasan normal paling banyak yaitu mahasiswa semester I $(\mathrm{n}=35)$. Hal ini dapat disebabkan karena mahasiswa semester I masih berada pada masa adaptasi dari SMA dan perguruan tinggi sehingga kuantitas tugas yang diberikan lebih sedikit dibandingkan dengan mahasiswa semester atas. Tingkat kecemasan kategori sangat parah mayoritas diderita oleh mahasiswa semester VI $(n=13)$. Hasil tersebut berbeda dibandingkan penelitian sebelumnya yang menunjukkan tingkat kecemasan mahasiswa semester I (25\%) lebih tinggi dibandingkan semester VI (11\%) (Chandratika dan Purnawati, 2014).

Data profil tingkat kecemasan responden mahasiswa profesi apoteker dapat dilihat pada Gambar 2. Sebagian besar mahasiswa PSPA memiliki tingkat kecemasan kategori normal yaitu angkatan $35(\mathrm{n}=49)$, angkatan $36(\mathrm{n}=27)$, dan angkatan $37(\mathrm{n}=40)$. Selain itu, mahasiswa yang memiliki tingkat kecemasan sedang juga cukup banyak, angkatan $35(\mathrm{n}=20)$, angkatan $36(\mathrm{n}=12)$,

Seminar Nasional Asosiasi Perguruan Tinggi Farmasi Indonesia (APTFI) III-Tantangan Pandemik (covid-19) dalam pembelajaran dan penelitian kefarmasian 16-20 Agustus 2021 (Virtual Conference) 
dan angkatan $37(n=16)$. Secara umum, hanya sebagian kecil mahasiswa yang mengalami kecemasan kategori sangat parah dengan jumlah responden paling banyak pada angkatan $37(n=4)$.

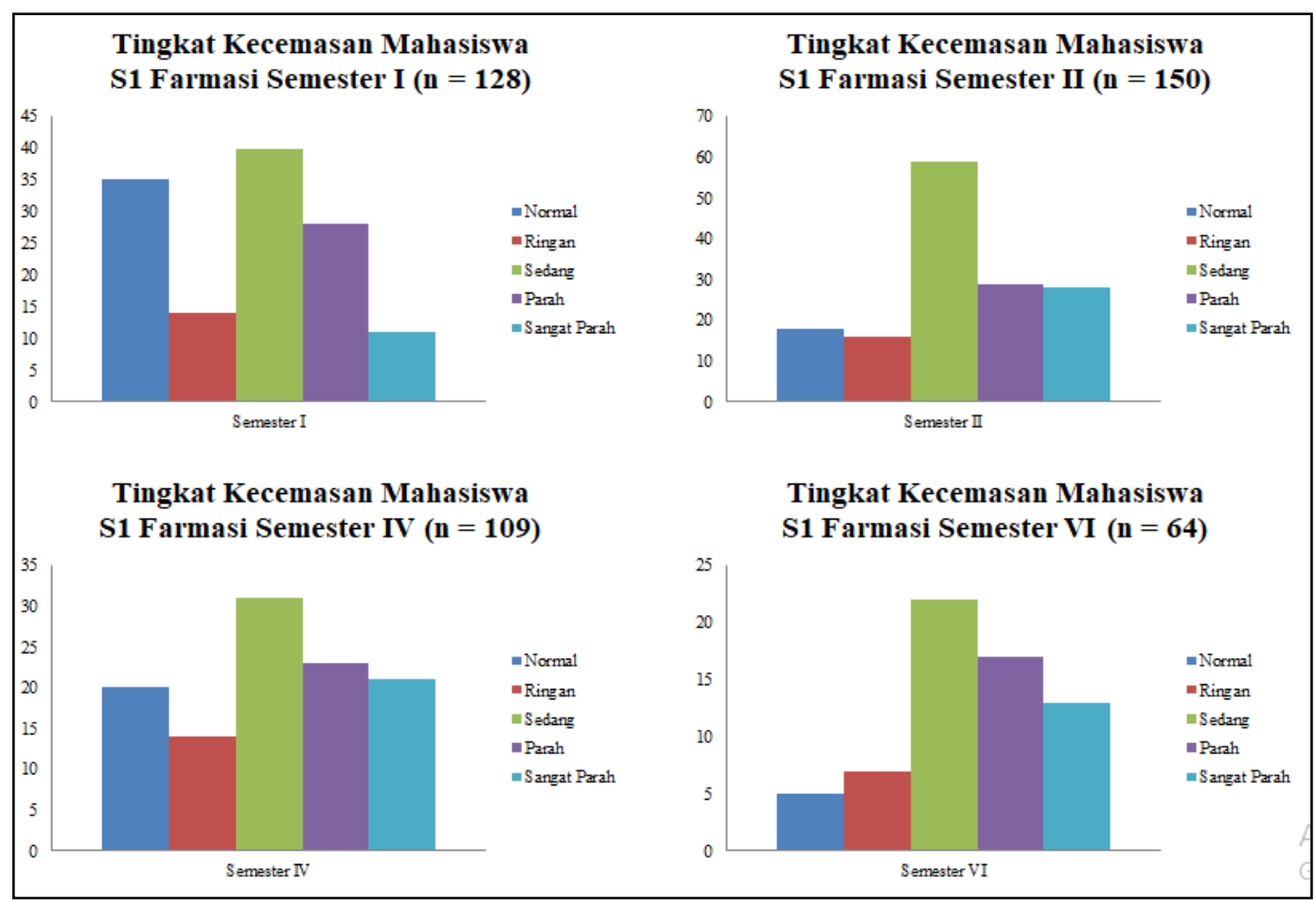

Gambar 1. Profil tingkat kecemasan mahasiswa S1 Farmasi

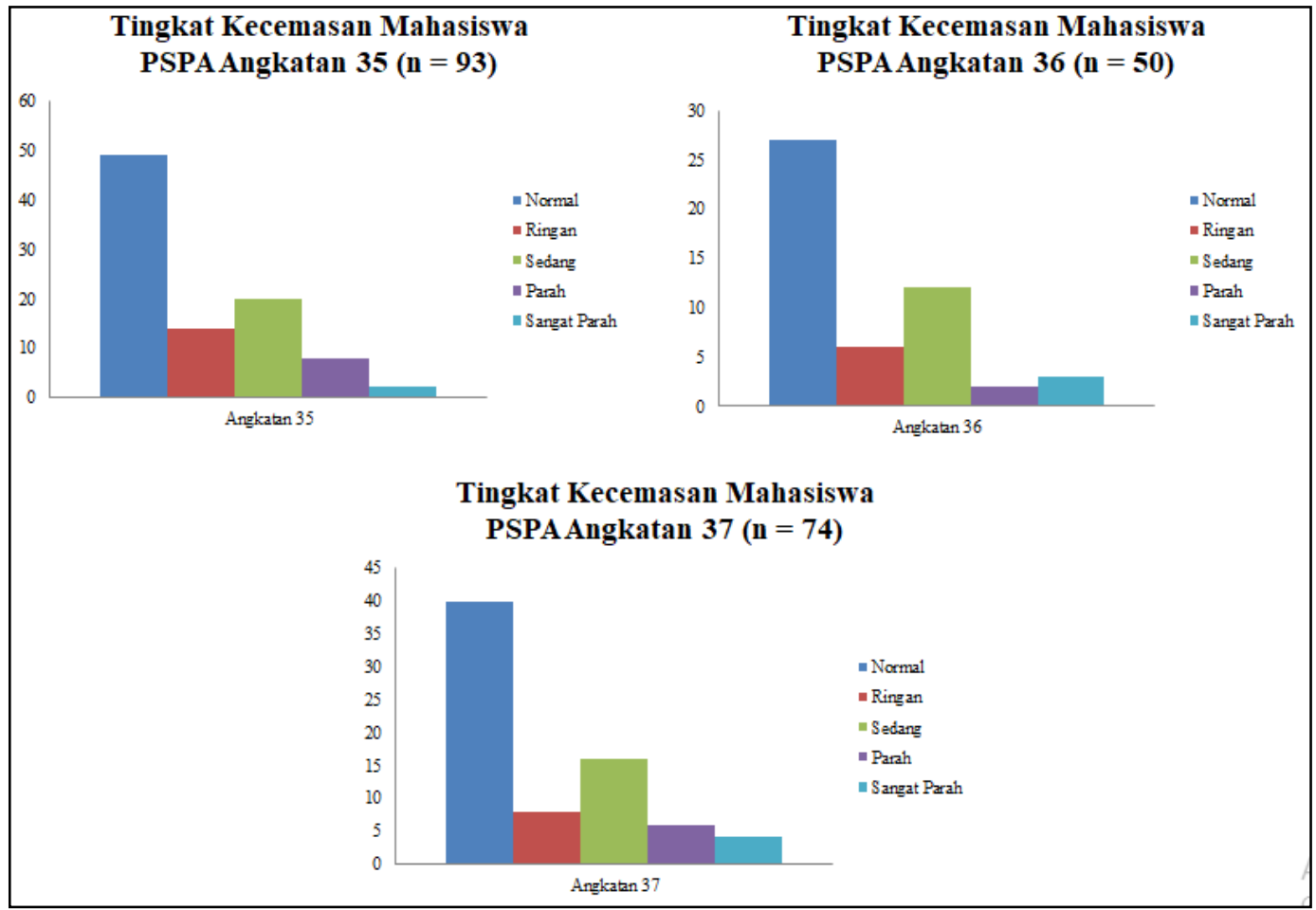

Gambar 2. Profil tingkat kecemasan mahasiswa PSPA

Seminar Nasional Asosiasi Perguruan Tinggi Farmasi Indonesia (APTFI) III-Tantangan Pandemik (covid-19) dalam pembelajaran dan penelitian kefarmasian 16-20 Agustus 2021 (Virtual Conference) 


\subsection{Profil tingkat stress}

Profil tingkat stress responden mahasiswa S1 Farmasi menunjukkan mayoritas mahasiswa tingkat stress normal. Tingkat kecemasan ringan paling banyak diderita mahasiswa semester II $(n=28)$. Pada semester I dan II tidak ada mahasiswa yang memiliki tingkat stress sangat parah, namun pada semester IV dan VI terdapat mahasiswa yang mengalami stress sangat parah yaitu 2 dan 1 responden (Gambar 3). Begitu pula pada mahasiswa PSPA juga sebagian besar memiliki kategori stress normal, namun tidak ada mahasiswa yang mengalami stress sangat parah. Terdapat mahasiswa yang memiliki stress kategori ringan, yaitu angkatan $35(n=10), 36(n=3)$, dan 37 (n=9). Stress dapat muncul karena kemampuan individu dan tuntutan yang tidak seimbang sehingga kesenjangan yang semakin besar dapat menyebabkan tingkat stress yang lebih tinggi (Tabroni et. al., 2021).

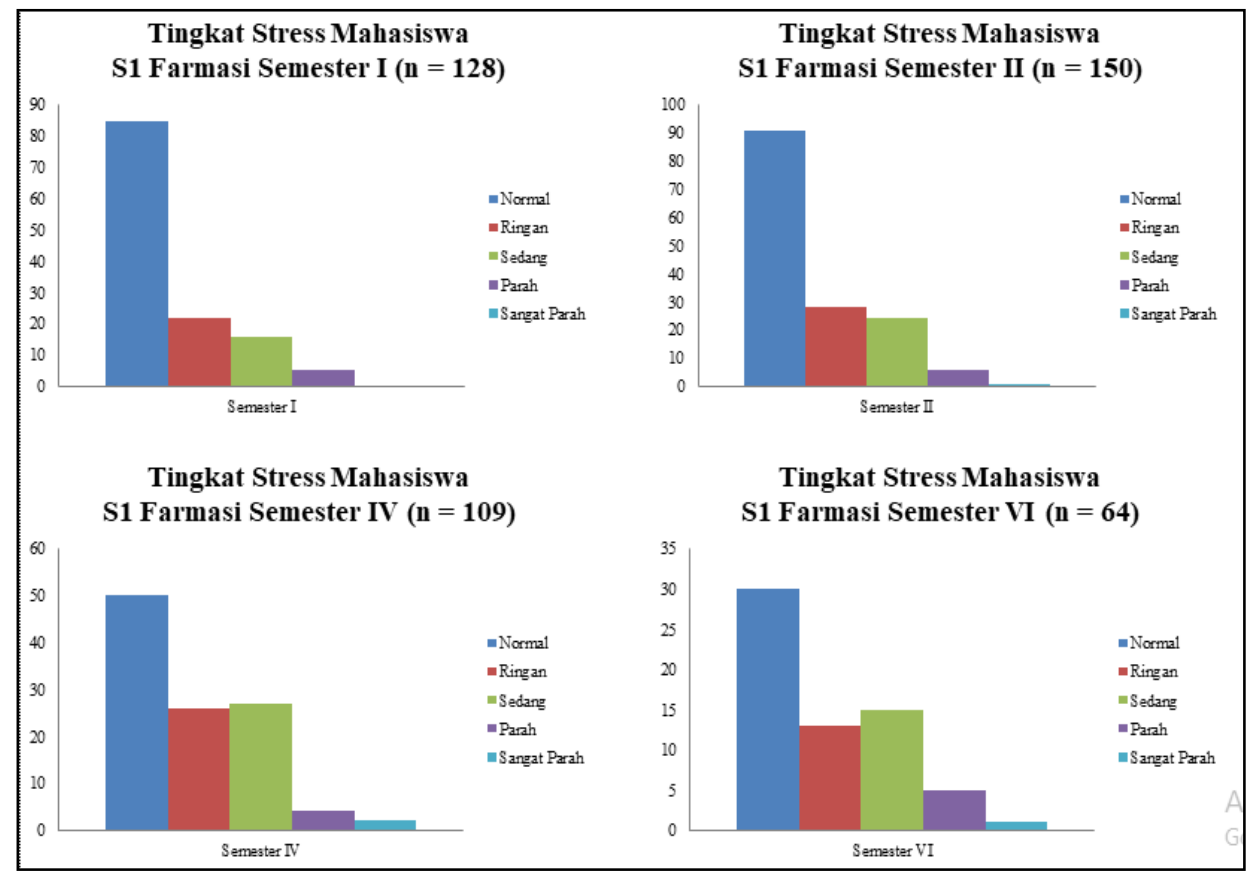

Gambar 3. Profil tingkat stress mahasiswa S1 Farmasi

\subsection{Profil tingkat depresi}

Pada semester I dengan total 128 responden, terdapat 4 responden dengan tingkat depresi sangat parah, 10 responden dengan tingkat parah, 19 responden dengan tingkat sedang, 23 responden dengan tingkat ringan, dan 72 responden dengan tingkat normal. Secara umum, dapat dikatakan bahwa tingkat depresi mahasiswa S1 farmasi pada semester I ini adalah ringan. Di semester II dengan total 150 responden, terdapat 4 responden dengan tingkat depresi sangat parah, 10 responden dengan tingkat parah, 40 responden dengan tingkat sedang, 24 responden dengan 
tingkat ringan, dan 72 responden dengan tingkat normal. Secara umum, dapat dikatakan bahwa tingkat depresi mahasiswa S1 farmasi pada semester II ini adalah ringan.

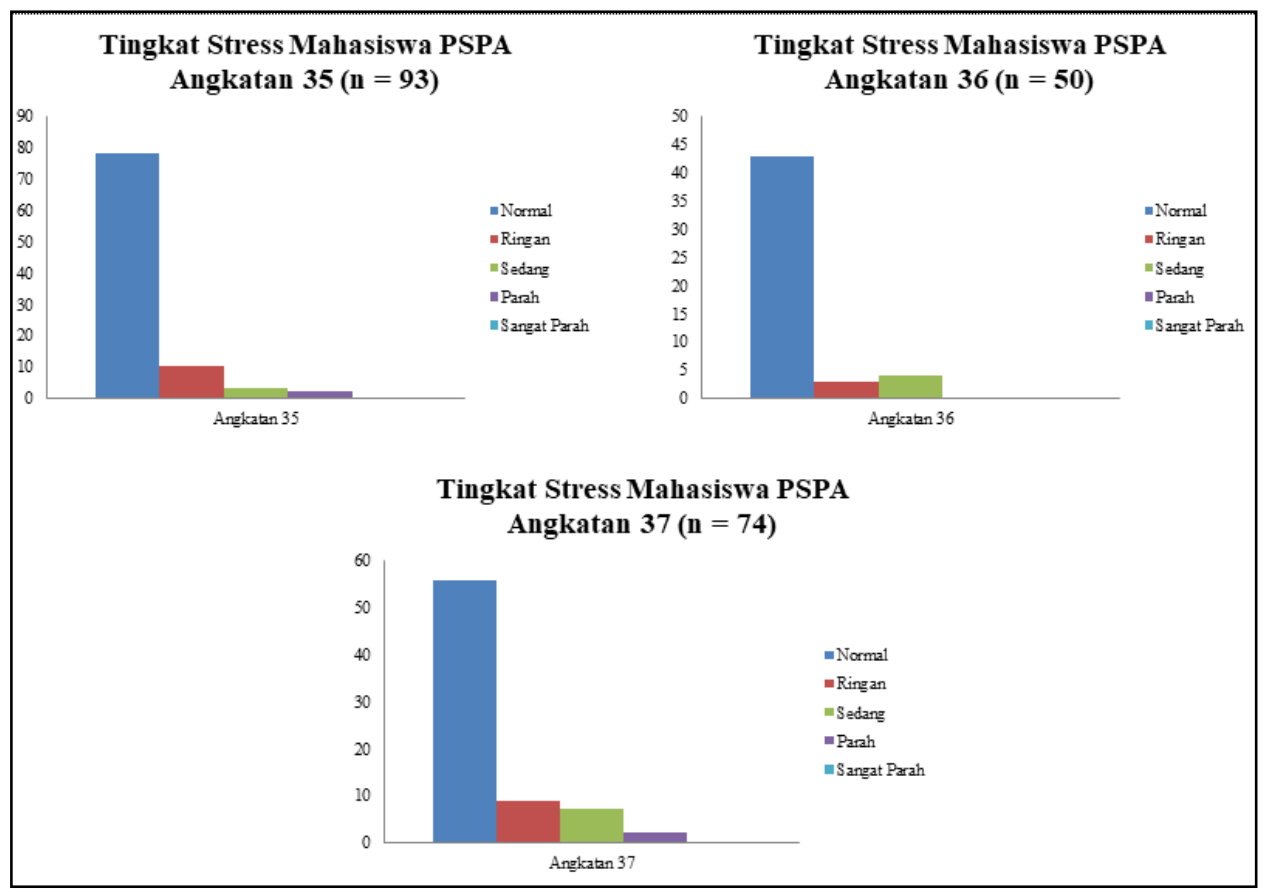

Gambar 4. Profil tingkat stress mahasiswa PSPA

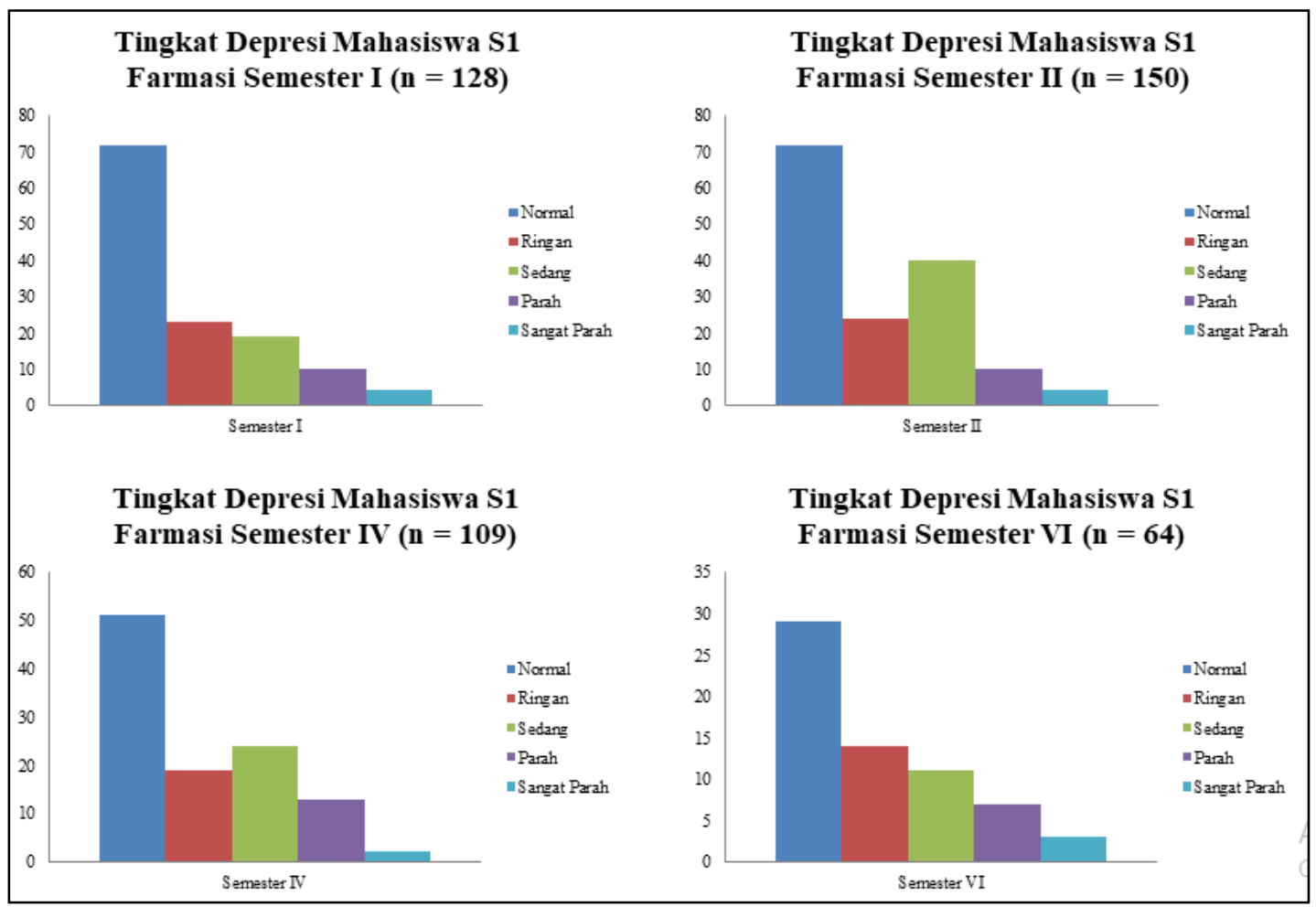

Gambar 5. Profil tingkat depresi mahasiswa S1 Farmasi

Seminar Nasional Asosiasi Perguruan Tinggi Farmasi Indonesia (APTFI) III-Tantangan Pandemik (covid-19) dalam pembelajaran dan penelitian kefarmasian 16-20 Agustus 2021 (Virtual Conference) 
Terdapat 2 responden dengan tingkat depresi sangat parah, 13 responden dengan tingkat parah, 24 responden dengan tingkat sedang, 19 responden dengan tingkat ringan, dan 51 responden dengan tingkat normal pada mahasiswa semester IV. Secara umum, dapat dikatakan bahwa tingkat depresi mahasiswa S1 farmasi pada semester IV ini adalah ringan. Di semester VI dengan total 64 responden, terdapat 3 responden dengan tingkat depresi sangat parah, 7 responden dengan tingkat parah, 11 responden dengan tingkat sedang, 14 responden dengan tingkat ringan, dan 29 responden dengan tingkat normal. Secara umum, dapat dikatakan bahwa tingkat depresi mahasiswa S1 farmasi pada semester VI ini adalah ringan (Gambar 4).

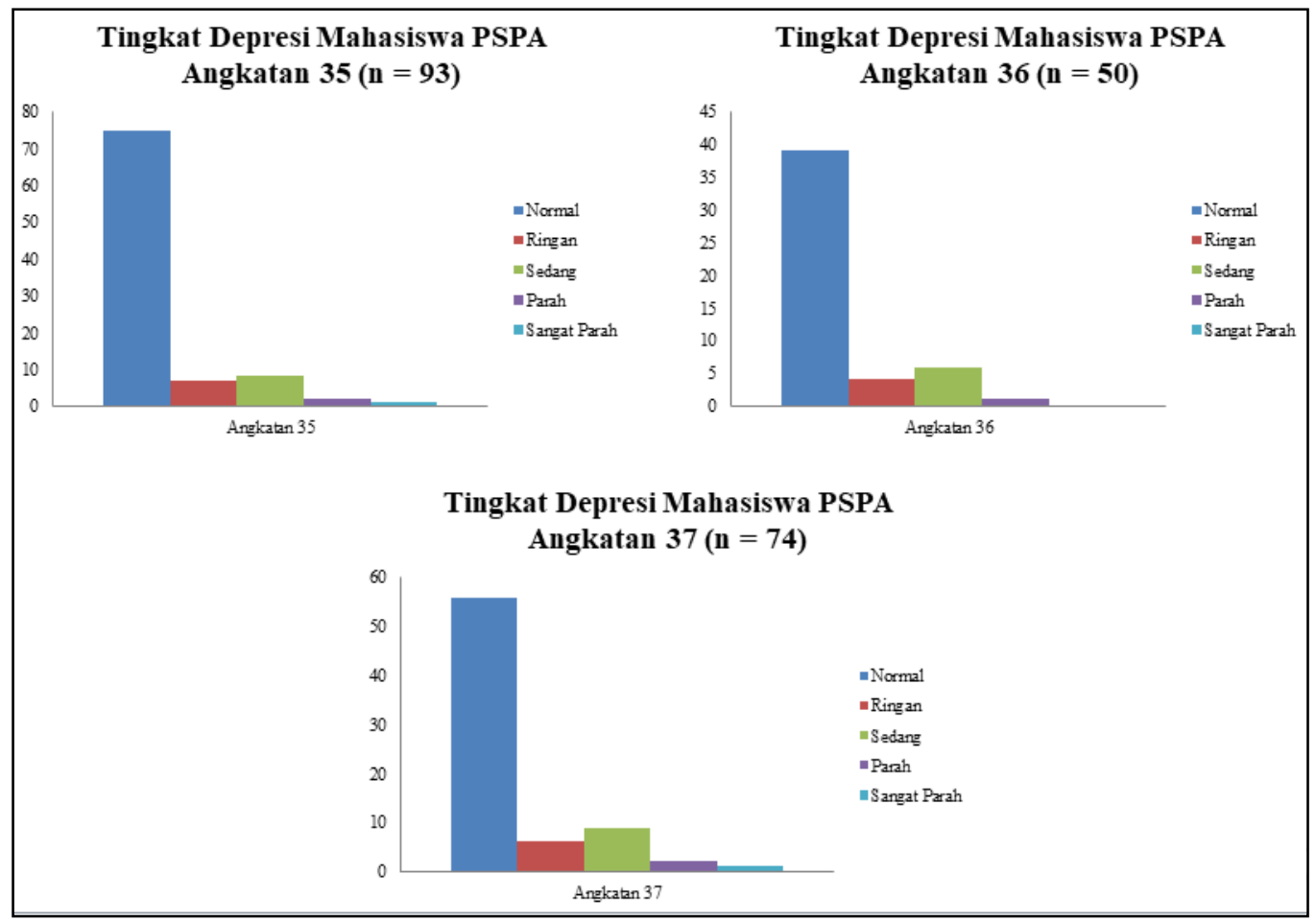

Gambar 6. Profil tingkat depresi mahasiswa PSPA

Data profil tingkat depresi mahasiswa profesi apoteker menunjukkan sebagian besar responden tidak mengalami depresi (depresi kategori normal). Mahasiswa yang mengalami depresi pada angkatan 35, 36, dan 37 yaitu sejumlah 8, 6, dan 9 responden. Penelitian serupa yang dilakukan oleh Asif, Saba \& Muddassar, Azka \& Zainab, Talala \& Raouf, Mobeen \& Pervaiz, Tehmina (2020) menunjukkan bahwa kalangan mahasiswa prevalensi depresi dalam rentang normal (25\%), ringan (16\%), sedang $(35,8 \%)$, berat $(14,6 \%)$ dan sangat parah $(8,6 \%)$. Prevalensi kecemasan ditemukan dalam rentang normal $(11,6 \%)$, ringan $(4,4 \%)$, sedang $(19,4 \%)$, berat $(17,8 \%)$ dan sangat parah $(46,8 \%)$. Stres normal $(15,6 \%)$, ringan $(33,8 \%)$, sedang $(35,4 \%)$, berat $(13,2 \%)$ dan sangat berat (2,8\%). Disamping itu, terdapat pula penelitian dengan judul Stress, anxiety \&depression among medical undergraduate students \& their socio-demographic correlates melaporkan lebih dari separuh 
respondennya mengalami depresi (51,3\%), kecemasan (66,9\%) dan stres (53\%). Morbiditas ditemukan lebih banyak pada mahasiswa semester 5 dibandingkan mahasiswa semester 2 . Mahasiswa perempuan dilaporkan memiliki penilaian yang lebih tinggi dibandingkan dengan mahasiswa laki-laki (Iqbal et. al., 2015; Rizvi et al., 2015).

\section{Kesimpulan}

Kuesioner DASS efektif untuk mengidentifikasi tingkat kecemasan, stress, dan depresi responden. Mayoritas mahasiswa berada dalam kategori normal, namun masih ditemukan mahasiswa dengan kategori ringan hingga berat. Dengan demikian, kuesioner ini dapat digunakan oleh DPA (dosen pembimbing akademik) untuk memantau perkembangan mahasiswa terutama dalam hal skrining kecemasan, stress, dan depresi.

\section{Ucapan terimakasih}

Penelitian ini didanai oleh Direktorat Penelitian dan Pengabdian Masyarakat Universitas Islam Indonesia. Oleh karena itu, peneliti menghaturkan terimakasih atas kesempatan yang diberikan.

\section{Daftar pustaka}

Ashari dan Hartati, 2017, Hubungan Antara Stress, Kecemasan, Depresi dengan kecenderungan Aggressive Driving pada mahasiswa, Journal Empati, Januari 2017, Volume 6(1), 1-6

Asif, Saba \& Muddassar, Azka \& Zainab, Talala \& Raouf, Mobeen \& Pervaiz, Tehmina. (2020). Frequency of depression, anxiety and stress among university students. Pakistan Journal of Medical Sciences. 36. 10.12669/pjms.36.5.1873.

Dipiro, et all, 2011, Pharmacotherapy: A Pathophysiologic Approach, 10e, Chapter 70. Anxiety Disorders Generalized Anxiety Panic and Social Anxiety Disorders, McGraw-Hill Education, Companies, Inggris.

Chandratika, D., \& Purnawati, S., 2014, Gangguan Cemas Pada Mahasiswa Semester I Dan Vii Program Studi Pendidikan Dokter Fakultas Kedokteran Universitas Udayana. E-jurnal Medika Udayana, 3(4), 1-11.

Ghayas S, Shamim S, Anjum F, Hussain M. Prevalence and severity of depression among undergraduate students in Karachi, Pakistan: A cross sectional study. Trop J Pharm Res. 2014;13(10):1733-1738.

Iqbal S, Gupta S, Venkatarao E. Stress, anxiety \&depression among medical undergraduate students \& their socio-demographic correlates. Indian J Med Res. 2015;141(3):354-357. doi: 10.4103/0971-5916.156571.

Irmawati, B. R. (2008). Faktor-faktor yang mempengaruhi mahasiswa dalam memilih program studi di perguruan tinggi. Skripsi. Yogyakarta: Universitas Sanata Dharma.

Jadoon NA, Yaqoob R, Raza A, Shehzad MA, Zeshan SC. Anxiety and depression among medical students: A cross-sectional study. J Pak Med Assoc. 2010;60(8):699-702.

Seminar Nasional Asosiasi Perguruan Tinggi Farmasi Indonesia (APTFI) III-Tantangan Pandemik (covid-19) dalam pembelajaran dan penelitian kefarmasian 16-20 Agustus 2021 (Virtual Conference) 
Jogaratnam \& Buchanan, 2004, Balancing the demands of school and work: stress and employed hospitality students, International Journal of Contemporary Hospitality Management; 2004;16,4/5;ABI/INFORM Global pg. 237

Lovibond, 1995, Overview of the DASS and its uses: Lovibond (1995) Available at: http://www2.psy.unsw.edu.au/groups/dass//over.htm

Potter, P.A, Perry, A.G. Buku Ajar Fundamental Keperawatan: Konsep, Proses, dan Praktik. Edisi 4.Volume 2.Alih Bahasa : Renata Komalasari,dkk.Jakarta:EGC. 2005

Rizvi F, Qureshi A, Rajput AM, Afzal M. Prevalence of depression, anxiety and stress (by DASS scoring system) among medical students in Islamabad, Pakistan. Br J Med Res. 2015;8(1):69-75. doi: 10.9734/BJMMR/2015/17193.

Tabroni, I., Nauli, F. A., Arneliwati, 2021, Gambaran Tingkat Stres Dan Stresor Pada Mahasiswa Keperawatan Universitas Negeri. Jurnal Keperawatan, 13 (1), 149-164.

Seminar Nasional Asosiasi Perguruan Tinggi Farmasi Indonesia (APTFI) III-Tantangan Pandemik (covid-19) dalam pembelajaran dan penelitian kefarmasian 16-20 Agustus 2021 (Virtual Conference) 